\title{
Mapping data gaps to estimate biomass across Brazilian Amazon forests
}

\author{
Graciela Tejada1*, Eric Bastos Görgens ${ }^{2}$, Alex Ovando ${ }^{3}$ and Jean Pierre Ometto ${ }^{1}$
}

\begin{abstract}
Background: Tropical forests play a fundamental role in the provision of diverse ecosystem services, such as biodiversity, climate and air quality regulation, freshwater provision, carbon cycling, agricultural support and culture. To understand the role of forests in the carbon balance, aboveground biomass (AGB) estimates are needed. Given the importance of Brazilian tropical forests, there is an urgent need to improve AGB estimates to support the Brazilian commitments under the United Nations Framework Convention on Climate Change (UNFCCC). Many AGB maps and datasets exist, varying in availability, scale and coverage. Thus, stakeholders, policy makers and scientists must decide which AGB product, dataset or combination of data to use for their particular goals. In this study, we assessed the gaps in the spatial AGB data across the Brazilian Amazon forests not only to orient the decision makers about the data that are currently available but also to provide a guide for future initiatives.

Results: We obtained a map of the gaps in the forest AGB spatial data for the Brazilian Amazon using statistics and differences between AGB maps and a spatial multicriteria evaluation that considered the current AGB datasets. The AGB spatial data gap map represents areas with good coverage of AGB data and, consequently, the main gaps or priority areas where further biomass assessments should focus, including the northeast of Amazon State, Amapá and northeast of Pará. Additionally, by quantifying the variability in both the AGB maps and field data on multiple environmental factors, we provide valuable elements for understanding the current AGB data as a function of climate, soil, vegetation and geomorphology.

Conclusions: The map of AGB data gaps could become a useful tool for policy makers and different stakeholders working on National Communications, Reducing Emissions from Deforestation and Degradation (REDD+), or carbon emissions modeling to prioritize places to implement further AGB assessments. Only $0.2 \%$ of the Amazon biome forest is sampled, and extensive effort is necessary to improve what we know about the tropical forest.
\end{abstract}

Keywords: Amazon, Tropical forest, Carbon, Aboveground biomass, Data gaps, REDD+, Environmental factors

\section{Background}

Tropical forests play a fundamental role in the provision of ecosystem services such as biodiversity, food production, traditional knowledge and carbon cycling. Aboveground biomass (AGB) estimates are needed to understand the role of tropical forests in the global carbon budget (Pan et al. 2011).

In the Brazilian Amazon, the total AGB stock has been estimated by several sources, including forest inventory

\footnotetext{
* Correspondence: gracielatejadap@gmail.com

${ }^{1}$ Earth System Science Center (CCST), National Institute for Space Research (INPE), Av dos Astronautas 1758, São José dos Campos, SP 12227-010, Brazil Full list of author information is available at the end of the article
}

plots and remote sensing approaches (Saatchi et al. 2011, 2015; Baccini et al. 2012). Given the extension, complexity and diversity of landscapes in tropical forest areas, remote sensing is one of the best tools for estimating AGB (Saatchi et al. 2011, 2015). However, remote sensing methods are still dependent on the availability of AGB field data (e.g. inventory plots) to ensure proper calibration and validation and spatial extrapolation methods (Mitchard et al. 2014; Saatchi et al. 2015).

Differences in remote sensing products and field data have resulted in great discrepancies in the spatial distribution of AGB estimates on different AGB maps (Mitchard 
et al. 2014; Ometto et al. 2014; Tejada 2014). Previous studies have indicated that considerable spatial uncertainties exist in biomass estimates (Ometto et al. 2014; Tejada 2014). To tackle the uncertainty associated with biomass estimates, the IPCC guidelines on greenhouse gases (GHGs) (IPCC 2006) suggest using environmental factor maps to find classes or strata with homogeneous AGB (a process known as stratification). Nonetheless, stratification has inherent methodological challenges, such as selecting the environmental factor maps with proper classification schemes and quality as a function of the scale (IPCC 2006; Angelsen et al. 2012).

There is an urgent need to improve and validate biomass estimates to support Brazilian commitments in the context of climate change, such as the National Communications (NC) and Reducing Emissions from Deforestation and Degradation (REDD+) commitments under the United Nations Framework Convention on Climate Change (UNFCCC). Progressive evolution is expected because these aspects are a growing concern in the scientific and political communities (MMA 2015; Fearnside 2018). While improvements are not available, estimations have been performed using the current and available AGB databases and environmental factor maps. Whether for NC, REDD+ or carbon emissions modeling, stakeholders, policy makers and scientists have to decide which AGB product, dataset or combination of data to use based on the availability, scale and coverage.
In this study, we assessed the gaps in the spatial AGB data across the Brazilian Amazon forests not only to orient the decision makers about what data are currently available but also to provide a guide for future initiative support. To achieve this goal, we used the current AGB dataset coverage and analyzed the differences in the AGB maps. We contrasted the AGB maps and the RadamBrasil field data within different environmental factor maps, such as climate, soil, vegetation and geomorphology maps. The previous results were merged, and we obtained the gaps in the forest AGB spatial data referring to the places where data acquisition should be improved. In other words, we assessed priority areas for further AGB assessments in the Brazilian Amazon.

\section{Methods and materials}

Study area

The Brazilian portion of the Amazon Basin has an area of $3,869,653 \mathrm{~km}^{2}$ and covers $60 \%$ of the basin (Fig. 1). This study focuses on only the forest area considered intact by the Deforestation Monitoring Program (PRODES) in 2014 $\left(\sim 3,139,172 \mathrm{~km}^{2}\right)$ (INPE 2015) within the Brazilian Amazon biome (IBGE 2004a).

\section{AGB field and laser data}

We used extensive AGB data, which were collected by contacting the most important research groups involved

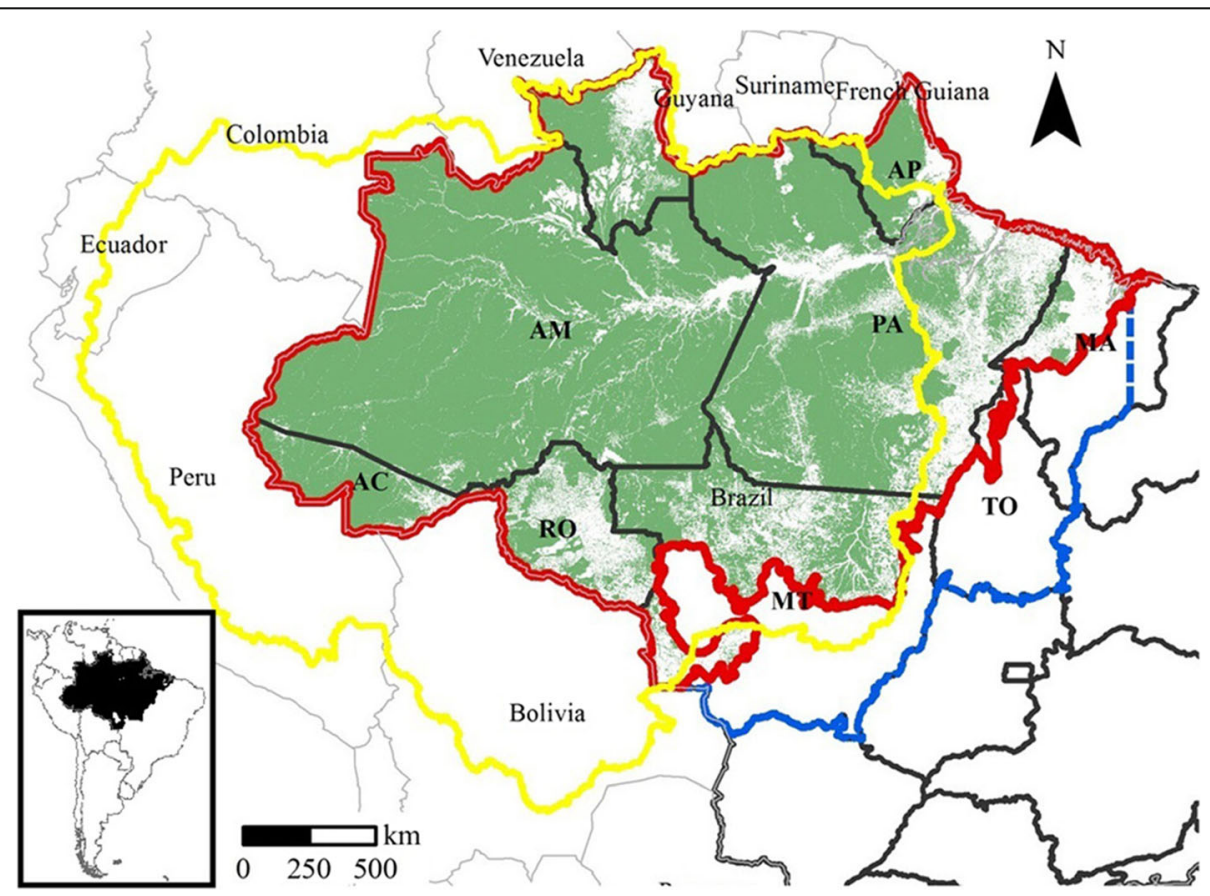

Fig. 1 Study area covering forests in the Brazilian Amazon biome. Brazilian Amazon biome forests, our study area (red line). The boundaries of the Brazilian Legal Amazon (blue line) and Amazon Basin (yellow line) are also shown. The 2014 forest mask data are from PRODES (INPE 2015) (green), and the Brazilian biome data are from IBGE (IBGE 2004a). The Brazilian states of Acre, Amazonas, Amapá, Mato Grosso, Maranhão, Pará, Rondônia, Roraima, and Tocantins are represented by AC, AM, AP, MT, MA, PA, RO and TO, respectively. Source: Tejada et al. (2019) 
in the subject. Both the data locations and methodology were registered in a geospatial database in Tejada et al. (2019). This study recorded 5351 AGB plots and 619, 858 ha of airborne laser scanning data in the Brazilian forest biome (Fig. 2 and Table 1).

\section{Forest AGB maps}

We chose five published AGB maps at the pantropical or Brazilian Amazon scale. At the pantropical scale, we selected the AGB maps published by Saatchi et al. (2011), Baccini et al. (2012) and Avitabile et al. (2016). The first two maps used LiDAR remote sensing data to extrapolate the field data. The AGB map of Avitabile et al. (2016) combined the maps from Saatchi et al. (2011) and Baccini et al. (2012) and included additional field data. At the Brazilian Amazon scale, we used the AGB maps published by Nogueira et al. (2015) and the third National Communication of Brazil (MCT 2016); both maps are based on field data extrapolated using vegetation classes. The AGB maps and their main characteristics are described in Table 2.

\section{Environmental factor maps}

We gathered information on five environmental factors: vegetation, soil, climate, topography and geomorphology. The maps came from different sources and are detailed in Table 3; further information is provided in Tejada et al. (2019).

The vegetation map of Brazil (IBGE and USGS 1992) was digitalized by the U.S. Geological Survey. The vegetation map (SIVAM 2002) was based on radar images and field work during the RadamBrasil project (RadamBrasil 1983) and was updated based on the SIVAM (Sistema de
Vigilância da Amazônia) project in 2002 (Malkomes et al. 2002). In 2004, the IBGE published a wall-to-wall map series at a 5 million scale, including the vegetation map of Brazil (IBGE 2004b), to reconstruct the original vegetation cover. The Brazilian Biological Diversity Project (PROBIO) combined all the previous vegetation mapping efforts by SIVAM, RadamBrasil, PRODES and IBGE (among many others) to generate a unique geographic database for the Amazon biome (MMA 2006a).

The soil map of Brazil (IBGE 2001) is part of the IBGE wall-to-wall maps at a 5 million scale using the Embrapa soil classification system and RadamBrasil data. The soil data were taken from the Legal Amazon map that was produced by the Ministry of Environment of Brazil (MMA) via the Environmental and Ecological Zoning project (ZEE) in the context of the scenarios for the Legal Amazon project and the IBGE (MMA 2006b). At the Amazon basin scale, the soil map from Quesada et al. (2011) was created using references for the RAINFOR forest sites with soil data. The map of the soil carbon stocks from Bernoux et al. (2002) links the vegetation and global soil classes of the IPCC (2006).

The climate map of Brazil is an update of a previous climate map from 1978 (Nimer 1979) that reflects the climate zones, thermic regions and wetness expressed by dry months (IBGE 2002a). The water deficit map shows the cumulative water deficit from 1988 to 2014 calculated by Fonseca et al. (2016) using Tropical Rainfall Measuring Mission (TRMM) data.

The relief map is part of the 4th IBGE Atlas (IBGE 2002b). To improve the original classification (i.e. the relief map), the relief map units were based on geomorphology classes at a 5 million scale and remote sensing images from the SIVAM

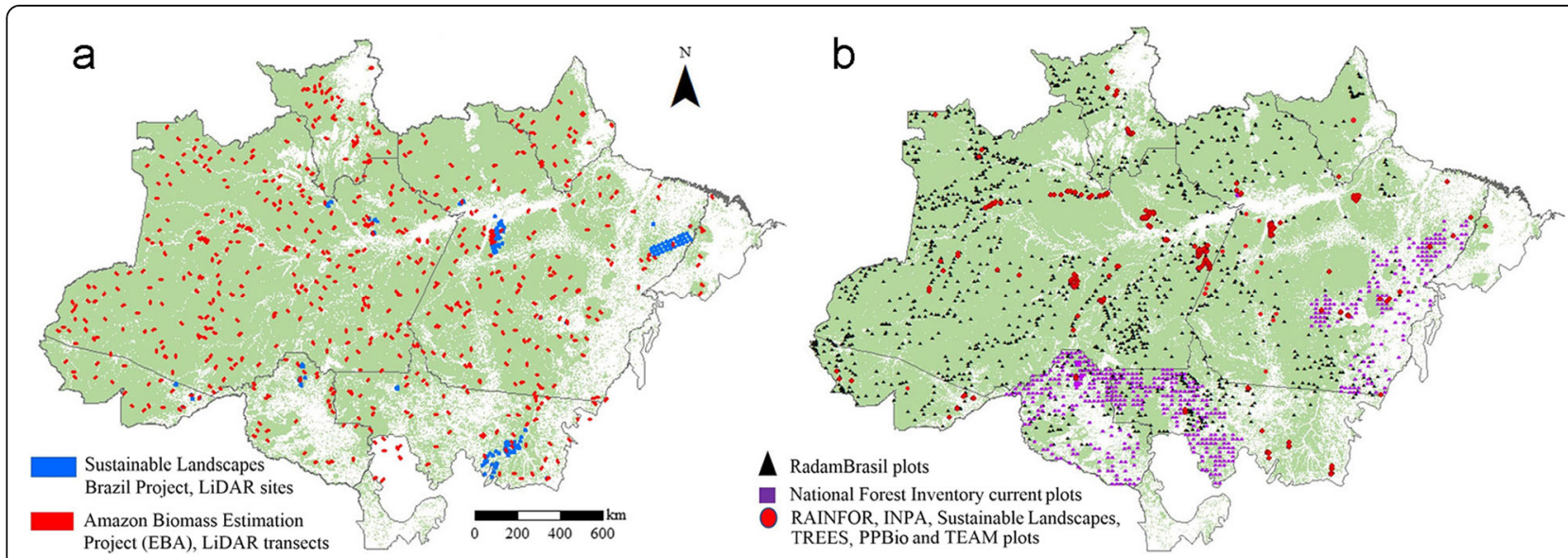

Fig. 2 Field plots and LiDAR transects in the Brazilian Amazon forest biome. a The LiDAR sites are from the Sustainable Landscapes Project (DosSantos and Keller 2016a; Sustainable-Landscapes 2016), and the LiDAR transects are from the Amazon Biomass Estimation subproject 7 (EBA 2016); b AGB field plots are from RadamBrasil (RadamBrasil 1983), Amazon Forest Inventory Network (RAINFOR) (RAINFOR 2015), National Forest Inventory (NFI 2016), Sustainable Landscapes Project (Dos-Santos and Keller 2016b; Sustainable Sustainable-Landscapes 2016), National Institute of Amazon Research (INPA) (personal communication), Tropical Ecosystems and Environmental Sciences Laboratory (TREES) (TREES 2016), Tropical Ecology, Assessment and Monitoring Network (TEAM) (TEAM Network 2016) and Research Program for Biodiversity (PPBio) (PPBio 2012). Source: Based on Tejada et al. (2019). 
Table 1 AGB plots and LiDAR sites per network in the Brazilian Amazon forest biome

\begin{tabular}{|c|c|c|c|c|c|c|c|c|c|c|c|c|}
\hline & \multicolumn{9}{|l|}{ Field plots } & \multicolumn{3}{|c|}{ LiDAR transects } \\
\hline & Radam Brasil & RAIN-FOR & $\mathrm{SL}$ & INPA & TREES & PPBio & $\mathrm{NFI}$ & TEAM & Total & $\overline{S L^{b}}$ & EBA & Total \\
\hline Plots per network & $1362^{\mathrm{a}}$ & 105 & 473 & $1374^{\mathrm{a}}$ & 49 & $458^{\mathrm{a}}$ & $1394^{\mathrm{a}}$ & 136 & 5351 & - & - & \\
\hline LiDAR Transects & - & - & - & - & - & - & - & - & & $\begin{array}{l}70 \\
\text { sites }\end{array}$ & 720 & \\
\hline $\begin{array}{l}\text { Percent of plots from } \\
\text { the total number of } \\
\text { plots }(\%)\end{array}$ & 25 & 2 & 9 & 26 & 1 & 9 & 26 & 3 & 100 & - & - & \\
\hline Area (ha) & 1362 & 405 & 115 & 1374 & 17 & 458 & 279 & 136 & 4045 & 44,764 & 575,094 & 619,858 \\
\hline Total forest area (ha) & & & & & & & & & & & $313,917,2$ & \\
\hline Percent of area from & 0.00043 & 0.00013 & 0.00004 & 0.00044 & 0.00001 & 0.00015 & 0.00090 & 0.00004 & 0.00132 & 0.014 & 0.183 & 0.19 \\
\hline
\end{tabular}

the total forest area

(\%)

Percent of total area $\quad 0.20$

(\%, plots and LiDAR)

\section{Source: Tejada et al. (2019)}

RAINFOR Amazon Forest Inventory Network, SL Sustainable Landscapes, TEAM Tropical Ecology, Assessment and Monitoring, INPA National Institute of Amazon Research, PPBio Research Program for Biodiversity, TREES Tropical Ecosystems and Environmental Sciences Laboratory, NFI National Forest Inventory, EBA Improving biomass estimation methods for the Amazon

${ }^{a}$ The number of plots for INPA, PPBio and RadamBrasil refers to those with location information. In the case of the NFI, the number of plots are those measured or in the process of measurement and include 192 plots of forest concessions

${ }^{b}$ In the case of SL LiDAR data, they work with sites, not transects. Each site could have a different number of transects. They have 70 sites along the

Brazilian Amazon

project (IBGE 2006). In the context of the ZEE project, we used the geomorphology map of the Legal Amazon (MMA $2006 \mathrm{~b})$ at 1:250000, which also used satellite images.

\section{Analyses of forest AGB variability and environmental factors}

First, we performed a variability analysis between the forest AGB maps, RadamBrasil field data and environmental factors. Then, the differences between the AGB maps were analyzed. For both analyses, we standardized the carbon pools of the AGB maps, removing the belowground biomass (BGB). The biomass maps from Saatchi et al. (2011), Baccini et al. (2012) and Avitabile et al. (2016) considered AGB and not BGB. However, MCT (2016) and Nogueira et al. (2015) considered both AGB and BGB. To compare these maps, we removed BGB using expansion factors (BGB is $25.8 \%$ of AGB) according to Nogueira et al. (2018).

Table 2 Main characteristics of the Amazon forest AGB density maps

\begin{tabular}{|c|c|c|c|c|c|c|c|}
\hline Map & Scale & $\begin{array}{l}\text { Spatial } \\
\text { resolution }\end{array}$ & $\begin{array}{l}\text { Temporal } \\
\text { scale (year) }\end{array}$ & $\begin{array}{l}\text { Field forest plots/ } \\
\text { source }\end{array}$ & $\begin{array}{l}\text { Study area plots/ } \\
\text { sampled area (ha) }\end{array}$ & $\begin{array}{l}\text { Remote Sensing products/ other } \\
\text { inputs }\end{array}$ & Model \\
\hline $\begin{array}{l}\text { Saatchi et al. } \\
\text { (2011) }\end{array}$ & Pantropical & $1 \mathrm{~km}$ & 2000 & $\begin{array}{l}4079^{\mathrm{b}}(493 \text { for } \\
\text { calibration)/ } \\
\text { Many sources }\end{array}$ & $\begin{array}{l}\sim 707 / \sim 1770^{\mathrm{d}} \\
\end{array}$ & $\begin{array}{l}\text { MODIS (NDVI, LAl, \% tree cover), } \\
\text { LiDAR from GLAS/Forest height } \\
\text { map }\end{array}$ & MaxEnt \\
\hline $\begin{array}{l}\text { Baccini et al. } \\
(2012)\end{array}$ & Pantropical & $500 \mathrm{~m}$ & $2007-2008$ & $283^{\mathrm{b}} /$ Measured & No Data & MODIS, LiDAR from GLAS, SRTM & $\begin{array}{l}\text { Random } \\
\text { Forest }\end{array}$ \\
\hline $\begin{array}{l}\text { Nogueira } \\
\text { et al. (2015) }\end{array}$ & $\begin{array}{l}\text { Brazilian } \\
\text { Amazon }\end{array}$ & $\begin{array}{l}1 \mathrm{~km} \\
\text { (landscape level) }\end{array}$ & $1970^{a}$ & $\begin{array}{l}2317^{c} / \text { RadamBrasil } \\
\text { and literature }\end{array}$ & $2373 / 2317$ & No/ Vegetation map (SIVAM 2002) & None \\
\hline MCT (2016) & $\begin{array}{l}\text { Brazilian } \\
\text { Amazon }\end{array}$ & $\begin{array}{l}1 \mathrm{~km} \\
\text { (landscape level) }\end{array}$ & $1973-1983^{a}$ & $\begin{array}{l}1682 \text { plots/ } \\
\text { RadamBrasil }\end{array}$ & $1682 / 1682$ & $\begin{array}{l}\text { No/ Vegetation (MCT 2010), Soils } \\
\text { (Bernoux et al. 2002) }\end{array}$ & $\begin{array}{l}\text { Inverse } \\
\text { distance } \\
\text { weighting }\end{array}$ \\
\hline $\begin{array}{l}\text { Avitabile } \\
\text { et al. (2016) }\end{array}$ & Pantropical & $1 \mathrm{~km}$ & $2000-2013^{a}$ & $\begin{array}{l}\text { 648/ RAINFOR, TEAM } \\
\text { and Sustainable } \\
\text { Landscapes }\end{array}$ & 500/ No data & No/ High-resolution AGB maps & $\begin{array}{l}\text { Fusion } \\
\text { model }\end{array}$ \\
\hline
\end{tabular}

Source: Based on Tejada et al. (2019)

RAINFOR Amazon Forest Inventory Network, TEAM Tropical Ecology, Assessment and Monitoring, MODIS moderate resolution imaging spectroradiometer, NDVI normalized difference vegetation index, LAl leaf area index, GLAS Geoscience Laser Altimeter System, LiDAR light detection and ranging, SRTM Shuttle Radar Topography Mission, and JERS-1 Japanese Earth Resources Satellite 1

${ }^{a} A G B$ field measurements

b we did not have access to the locations of the plots

$c_{\text {in }}$ the case of the RadamBrasil plots, we had the location of only 1682 plots

$d$ the total area of the plots was estimated because the plots had different sizes 


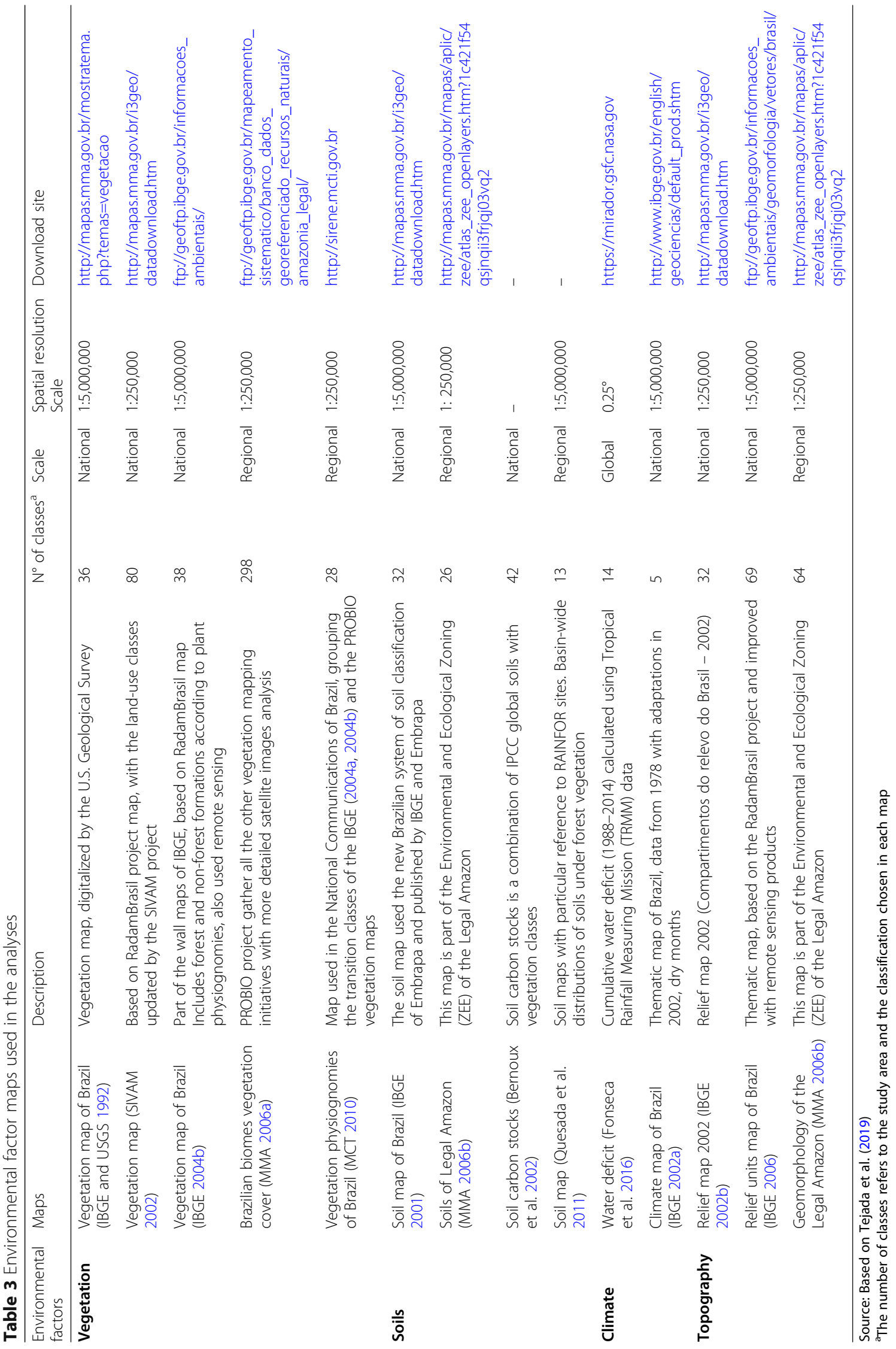


The variability in the AGB maps within the different environmental factor maps (soil, vegetation, topography and climate) was measured in terms of population variance (considering every environmental factor map, Eq. 1) and stratified variance (SV) (considering the environmental factor map classes, Eq. 2). The population and SV in the RadamBrasil field plot data were also calculated in each environmental factor map to compare the variance in the field data versus the variance in the AGB maps to see if the tendency of the AGB in the maps was corrected. As we had access to the data from the RadamBrasil field plots, we assumed that the AGB remained stable unless the area was deforested (we removed the deforested areas with the PRODES mask), as was assumed by many AGB maps that used this dataset (e.g. MCT 2010, 2016; Nogueira et al. 2015).

\section{Eq. 1 global variance}

$$
\sigma^{2}=\frac{\sum\left(X_{i}-\mu\right)^{2}}{N}
$$

where $X_{i}$ is an observation, $\mu$ is the population mean, and $N$ is the population size.

\section{Eq. 2 stratified variance}

$$
s^{2}=\sum_{i}^{n}\left(\frac{n_{j}}{N}\right)^{2} \times s_{j}
$$

where $s^{2}$ is the total stratified variance, $n$ is the size of stratum $j, N$ is the population size and $s_{j}$ is the sample variance in stratum $j$.

We expect that each class of an environmental factor map should be homogeneous. Therefore, the AGB should exhibit a smaller variance within a class than in the entire map. Stratification could help to reduce the cost and effort required to sample large areas by calculating the number of $\mathrm{AGB}$ plots needed to represent each class (Pearson et al. 2005; IPCC 2006).

We carried out SV analysis to identify the environmental factor maps (and classes) with low variance in the AGB maps and RadamBrasil. We expected that a class with lower AGB variance would better represent the AGB.

The differences between the AGB maps were analyzed from the two-by-two differences in the five AGB maps (Saatchi et al. 2011; Baccini et al. 2012; Nogueira et al. 2015; MCT 2016; Avitabile et al. 2016), generating 10 maps. Then, we calculated the cell statistics by combining all the AGB maps to obtain the average, standard deviation and range to summarize the tendencies.

\section{Map of the gaps in forest AGB spatial data}

To obtain the forest AGB data gap map, we performed a spatial multicriteria evaluation (SMCE) in the GIS integrated land and watershed management information system (ILWIS) environment (Meijerink et al. 1988) using the distance maps from the LiDAR transects and AGB plots and the standard deviation map of all AGB maps as inputs. For the SMCE, all the input maps were previously standardized to make them fully comparable, converting the original values to a 0 to 1 range, as shown in Fig. 3.

The distance and the standard deviation maps were conceived as a benefit factor, which, under the ILWIS-SMCE criterion, means that the higher the value is, the more it contributes to the goal. In this case, the goal is to map the gaps in the representativeness of the AGB data, including AGB maps and plots. Thus, areas with greater distances to the sampling plots or LiDAR transects and with higher standard deviation are more likely to be considered gaps. Areas with shorter distances to plots and high standard deviation will have an intermediate weight in the gap map.

\section{Results}

Forest AGB maps and environmental factors

As expected, the global variance in each AGB product (Fig. 4a) was higher than the SV considering each environmental factor (Fig. 4b). The soil maps had the highest SV among all environmental factors, except for the IBGE (2002a, 2002b) climate map. Relief, geomorphology, and the two vegetation maps (SIVAM 2002; MMA 2006a) showed the lowest SV. Climate had the highest SV. It is particularly interesting that the IBGE (2006) relief map had the lowest SV in the AGB maps among all environmental factor maps, being lower than even the PROBIO vegetation map (MMA 2006a), which has more detailed classes (except for the SV of the RadamBrasil field data).

The RadamBrasil field data had higher SV values than the AGB maps (Fig. 4b), except for the PROBIO (MMA 2006a) and SIVAM (2002) vegetation maps and the IBGE (2006) relief map. In terms of the SV in the AGB maps (Fig. 4b), the Saatchi et al. (2011) map had the lowest SV, followed by Nogueira et al. (2015) and Baccini et al. (2012) with intermediate SV values, with the exception of the SV in the vegetation maps, in which the Nogueira et al. (2015) map had the lowest SV. The SV was high in the MCT (2016) and Avitabile et al. (2016) maps.

Analysis of the climate maps (Fig. 5a and b) indicated that the classes with high precipitation and low water deficits were those with low SV. The climate maps with a few large classes had high SV.

The tendency among the five vegetation maps (Figs. $5 \mathrm{c}-$ g) is a high SV in the central Amazon (lowland dense humid forests or $\mathrm{Db}$ ) close to the main rivers and in the northeast (submontane dense humid forest or Ds). The large sizes of these two vegetation classes coincide in all vegetation maps and cover almost $50 \%$ of the total area (Fig. 5c, e, $\mathrm{f}$ and g), except for in the PROBIO vegetation map where these classes cover $30 \%$ of the area (Fig. $5 \mathrm{~d}$ ). If 


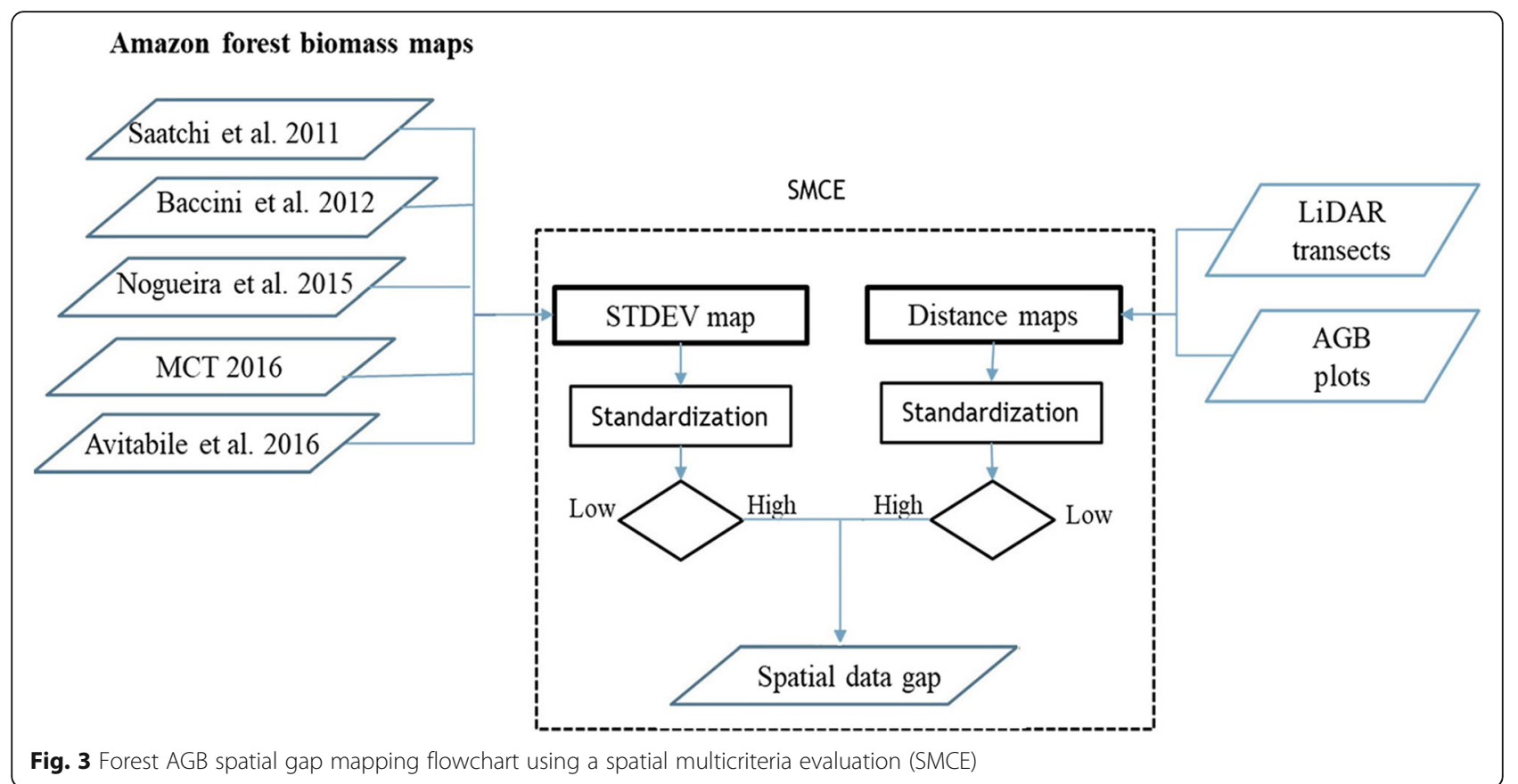

we consider the first 5 classes, they cover $70 \%$ of the area of all vegetation maps (except for in the PROBIO map, where they cover $57 \%$ of the area), showing that few classes represent large areas, reflecting high SV.

The vegetation maps with more classes, such as the PROBIO map (Fig. 5d) with 298 classes and SIVAM (2002) with 80 classes, have low SV. Additionally, the RadamBrasil field data have the lowest SV in these vegetation maps.

Of all the environmental factor maps, the IBGE (2006) relief (or geomorphology) map has the lowest SV with 69 classes (Fig. 6c); only two classes have high SV, depression of the Solimões River and depression of Southern Amazonia. However, these classes represent only $19 \%$ of the area, and the first five classes represent only $36 \%$ of the total map area.

The MMA (2006b) geomorphology map with 64 classes (Fig. 6a) presents low SV, with the exception of the convex dissection (Dc 53) and pediplain exposed (Pru) classes, which both covered $25 \%$ of the area, and the first five classes covered $40 \%$ of the total map area. The IBGE (2002b) relief map with only half as many classes (32) has a high SV (Fig. 6b), and the first 5 classes represent

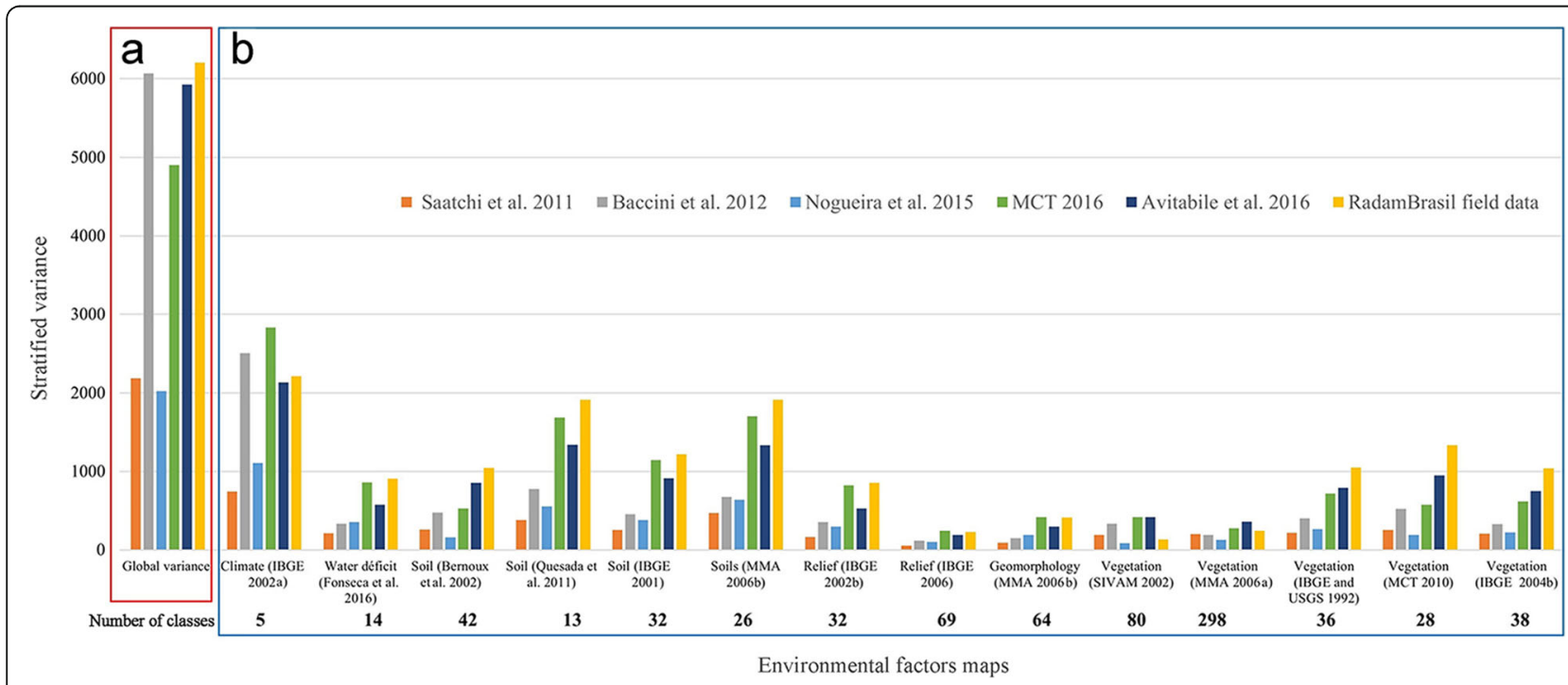

Fig. 4 Global and stratified variance in the AGB maps and the RadamBrasil data within each environmental factor map. a Global variance in each AGB map and RadamBrasil data; $\mathbf{b}$ stratified variance in the AGB maps and RadamBrasil AGB field data within each environmental factor map 


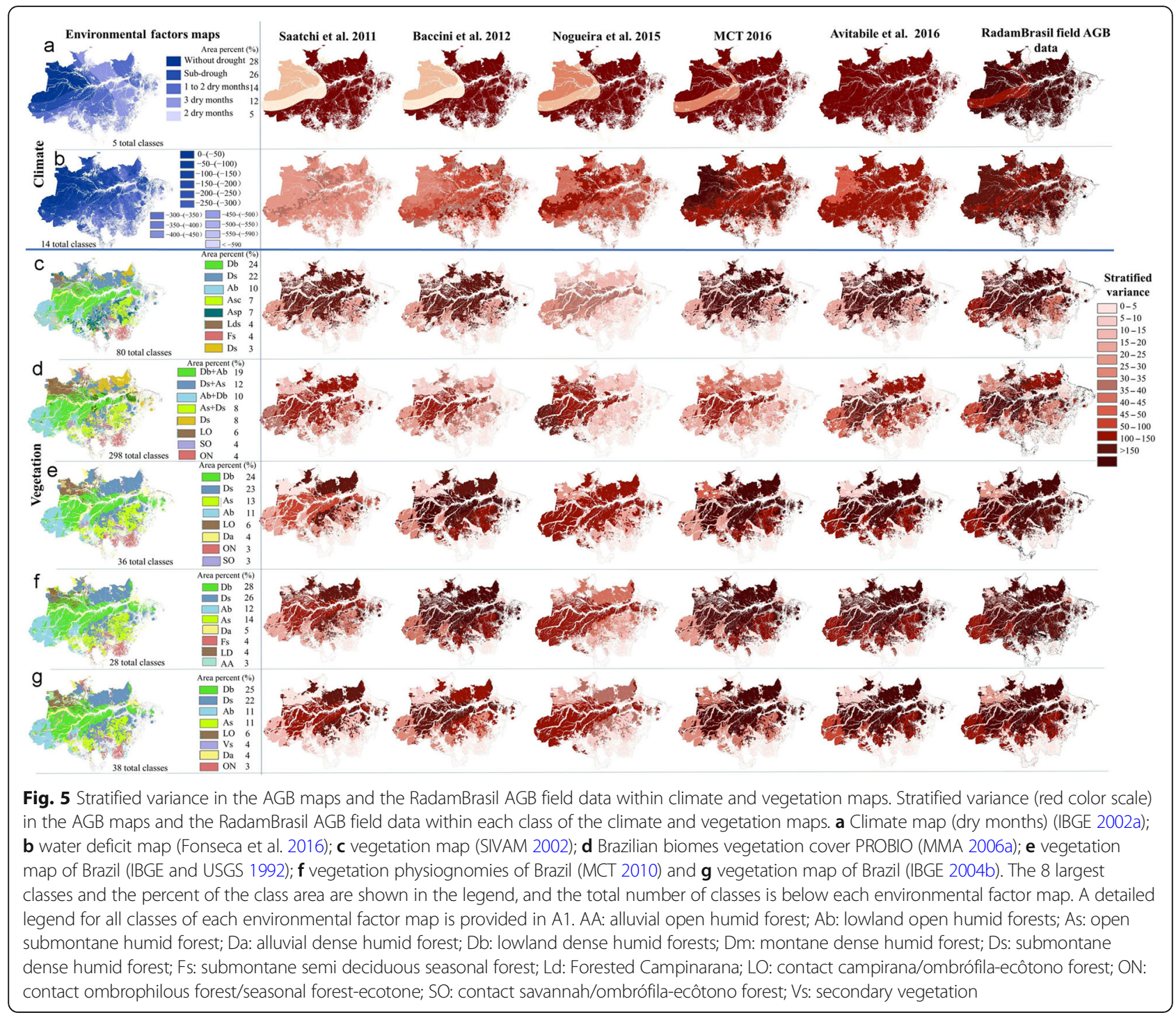

$70 \%$ of the total map area. This result indicates that many classes with uniform sizes (Fig. 6a and c) have lower SV than those with few large classes (Fig. 6b).

Considering the SV in each class of each environmental factor, soil had the highest SV. The high activity clay soils with an open Amazon forest class, the southwest classes (Fig. 7d), and the podzol hydromorphic class (Fig. 7e) have low SV, possibly because of the small sizes of these classes. The soil map of Bernoux et al. (2002) indicates that the Nogueira et al. (2015) AGB map has a lower SV than the rest of the maps, possibly because it considers vegetation, while the rest of the AGB maps have high SV. The first two classes of the soil maps covered almost $50 \%$ of the total area, showing many large classes with high SV and few with low SV.

\section{Analysis of differences between forest AGB maps}

As the AGB maps are a result of several AGB datasets, it is interesting to determine where the main differences and similarities in the AGB estimates occur. It is assumed that the places with the greatest AGB similarities are the places with better biomass estimates (Fig. 7).

The main difference between the Saatchi et al. (2011) and Baccini et al. (2012) maps is in the west-central Amazon (Amazonas State). The Avitabile et al. (2016) map is similar to the Saatchi et al. (2011) map, with differences mainly in Amapá, Northeast Pará and Amazonas State close to the Acre limits (Fig. 7). The Baccini et al. (2012) map exhibits specific differences from the Nogueira et al. (2015) map in Roraima and south Amazonas State, as well as differences with the MCT (2016) map in central Amazon and the Avitabile et al. (2016) map in Amapá and northeast Pará. The Avitabile et al. (2016) map differs greatly from the Nogueira et al. (2015) and MCT (2016) maps. Although they used the same field data and a similar extrapolation method, the MCT (2016) and Nogueira et al. (2015) maps exhibit substantial differences. The average AGB map has fewer 


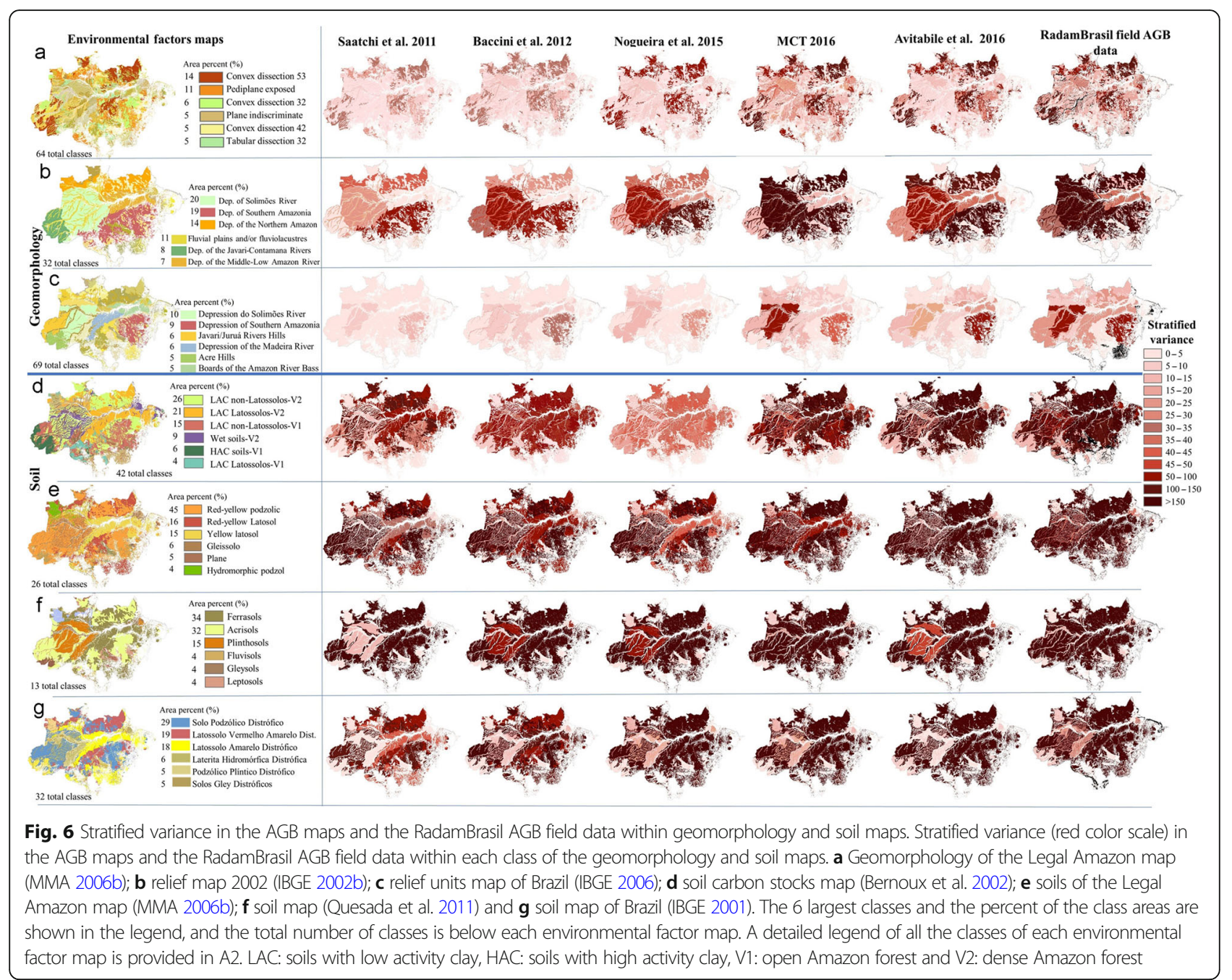

extremes; in other words, the areas with high biomass (the limit between Acre and Amazonas State and in Amapá and northeast of Pará) are not high if you compare them to the MCT (2016) or Avitabile et al. (2016) maps.

By calculating the cell statistics throughout the AGB maps, it is possible to see that the extreme differences are next to rivers, mainly the Amazon River in Amapá and northeast of Pará. The standard deviation (Fig. 8) calculated from this set of AGB maps objectively explains the magnitude of these differences. Additionally, the range, which is the difference between the maximum and minimum $\mathrm{AGB}$ values, represents the discrepancies among the AGB maps. Most of the differences in the standard deviation map are found in the west-central and northwestern Amazon. The extremes are along the riverbanks in Amapá and northeast of Pará.

\section{Forest AGB spatial data gap map}

The final map of the gaps in the AGB spatial data (Fig. 9) shows the areas with high gaps in red and the areas that have moderate coverage of field and LiDAR data in orange where the differences in AGB are intermediate. Yellow areas are the places that have good coverage of AGB plots and LiDAR transects and where the AGB maps exhibit great similarities. Consequently, the main gaps or priority areas where further biomass assessments should be focused are the northeast of Amazon State, Amapá, northeast of Pará and along the rivers.

\section{Discussion}

According to Goetz et al. (2009), there are different approaches to map carbon stocks: the direct remote sensing (DR) approach and the stratify and multiply (SM) approach. According to our analysis, AGB maps that are derived from the DR approach (e.g. Saatchi et al. 2011; Baccini et al. 2012; Avitabile et al. 2016) have lower AGB values than the maps derived from the SM approach (e.g. Nogueira et al. 2015; MCT 2016) (see Fig. 7). The reason for this difference is that the maps created using the DR approach reflect the actual biomass and consider forest 

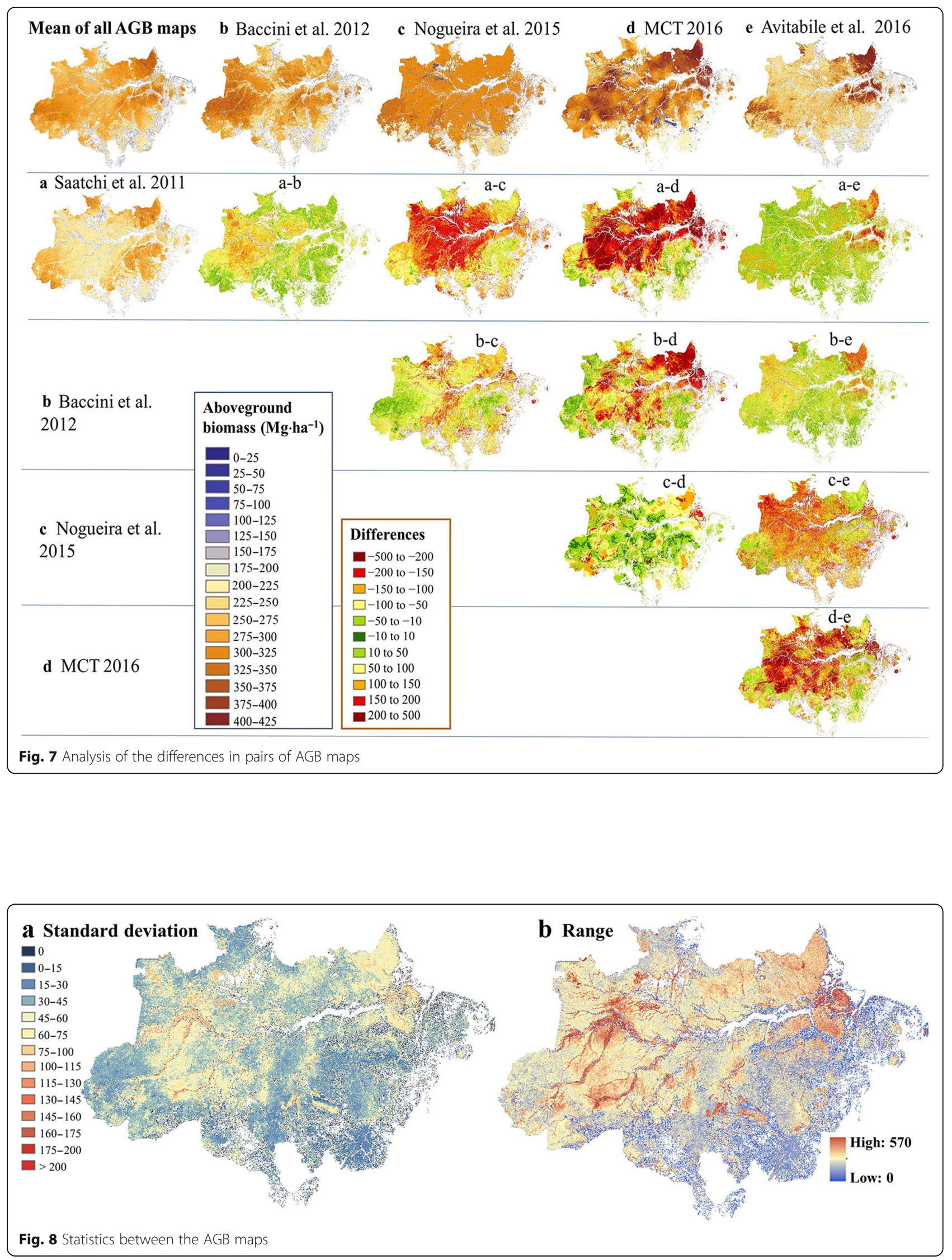


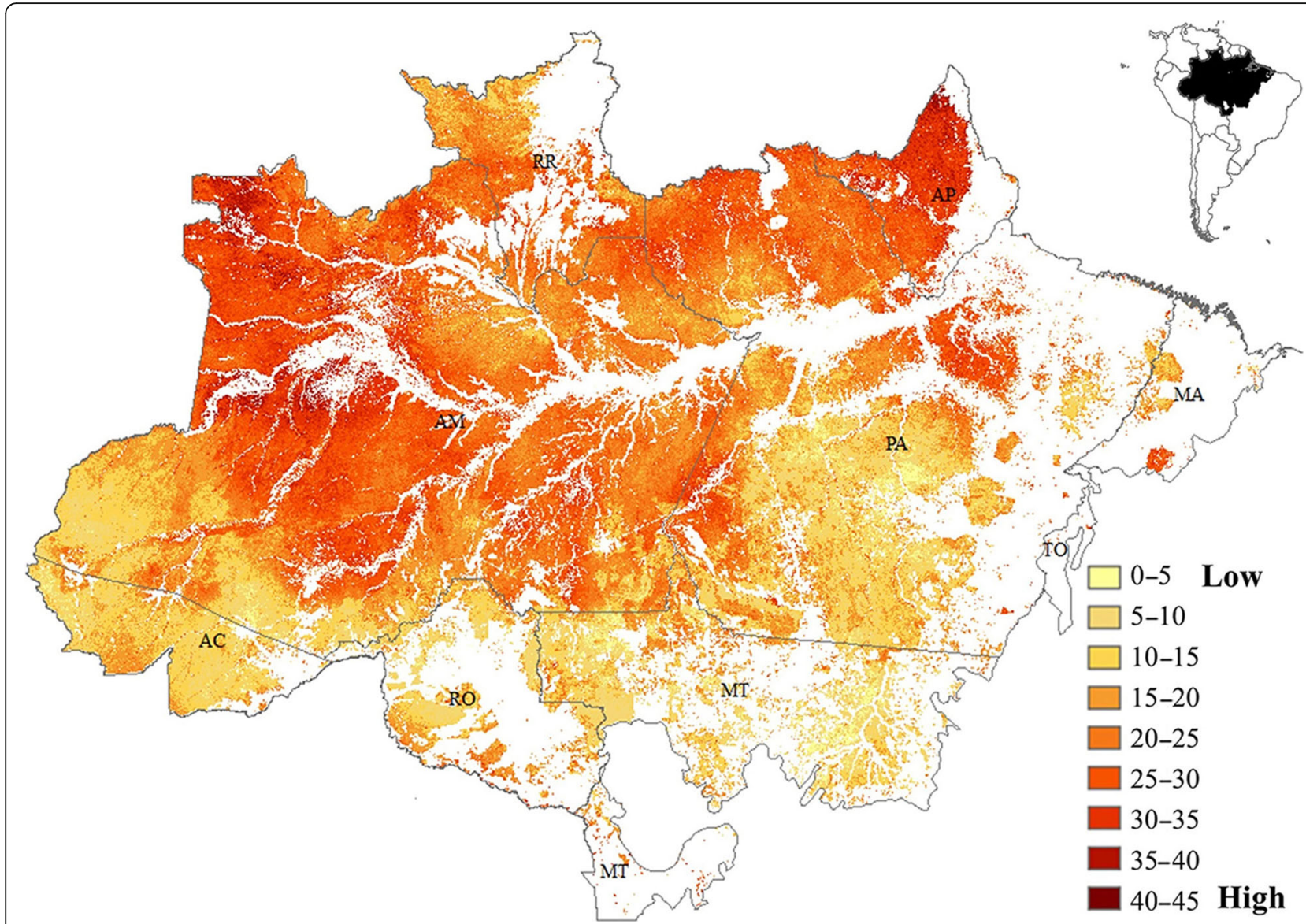

Fig. 9 Map of the gaps in spatial AGB data developed using spatial multicriteria analysis. The Brazilian states of Acre, Amazonas, Amapá, Mato Grosso, Maranhão, Pará, Rondônia, Roraima, and Tocantins are represented by AC, AM, AP, MT, MA, PA, RO and TO, respectively

degradation (deforestation areas were removed by using a forest mask), while the SM maps represent the potential biomass per vegetation class. The differences between the DR maps are located in specific places (west Amazon, Amapá, northeast of Pará), while there are larger areas with substantial differences in the SM maps due to the large areas with high biomass values (whole Amazon State, west Pará and the same places as those in the DR maps) (Figs. 7 and 8). On the other hand, the differences in scale between the SR and SM maps are worth mentioning. The DR maps represent a pantropical scale, which applies general assumptions to extrapolate the AGB, while the SM maps are conceived specifically for the Brazilian Amazon and adopt local assumptions.

To obtain a stratification adherent to the IPCC (2006) guidelines and the Voluntary Carbon Standard (VCS 2015), the ideal is to combine environmental factors to represent the AGB distribution in the Brazilian Amazon. Our SV results show great variation in terms of the SV between the AGB maps and AGB RadamBrasil field data. The reason could be the different acquisition-generation dates between RadamBrasil field data (from 1973 to 1983) and some AGB maps (i.e. Nogueira et al. 2015; MCT 2016). The AGB maps of MCT (2016) and Nogueira et al. (2015) (both with SM approach) used the RadamBrasil field data that do not consider the degradation of later years, since our mask removes only deforested areas. However, the AGB maps of Saatchi et al. (2011), Baccini et al. (2012) and Avitabile et al. (2016) (all with the RS approach) considered degradation and represent the 2000s. Another reason why RadamBrasil field data have higher variance is that they alone do not represent the large size of the main vegetation classes, which is why the AGB maps used other inputs, such as remote sensing images and models.

The SV analysis also showed that the number and size of environmental factor classes influence the variance. The PROBIO map (MMA 2006a) with 298 classes has the lowest $\mathrm{SV}$ of all the vegetation maps, followed by the SIVAM (2002) with 80 classes. The relief map from the IBGE (2006) with 69 classes also has low SV. The RadamBrasil field data served as a reference during the calculation of the AGB with the field plots, and in these three maps, the SV was lower than that in the rest of the environmental factor maps. 


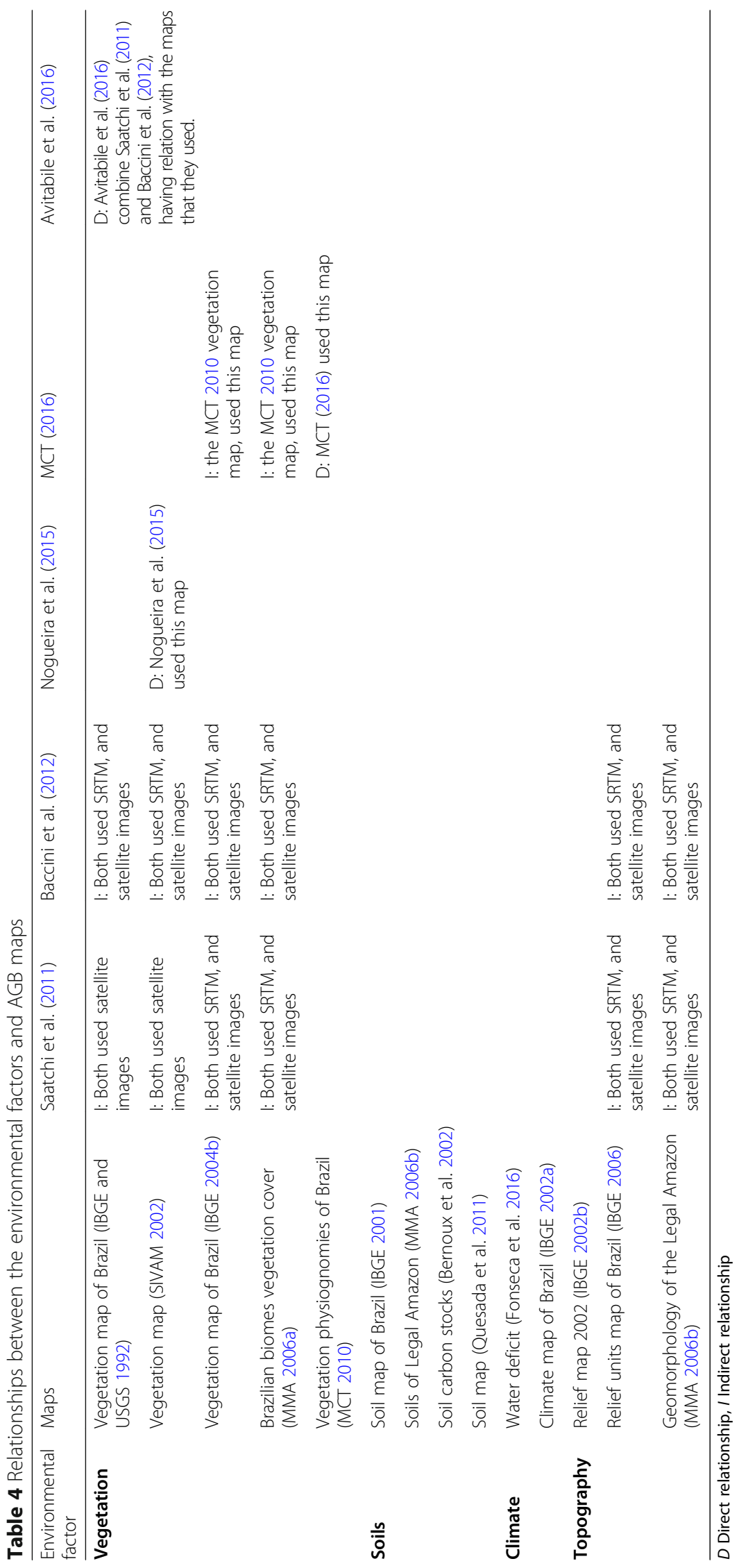


The geomorphology map of MMA (2006b) with 64 classes had low SV values, except in the RadamBrasil field data. The relief map (IBGE 2002b) and vegetation maps (IBGE and USGS 1992; IBGE 2004b; MCT 2010) with few classes had moderate SV, while the three soil maps and the climate map (IBGE 2002a) had the highest SV. The water deficit map was a continuous map, so we could classify the map into more classes, and the SV had relatively low values. This map could be further explored for its use as an AGB indicator.

Many AGB maps exhibit a direct relationship with one or many environmental factor maps. A specific environmental factor map could be used to produce the AGB map (Table 4). Although direct and indirect relationships exist, we chose to keep all the variance analyses to see how these relationships influence the SV. It could be useful to understand when the variance is reduced due to dependency. For example, the low SV in the Nogueira et al. (2015) map in the SIVAM (2002) vegetation map is due to a direct relationship between them (this vegetation map was used to extrapolate AGB) (Table 4). The Saatchi et al. (2011) and Baccini et al. (2012) AGB maps also show an indirect relationship with the PROBIO map with regard to the SRTM digital elevation model, which was also used in the relief map (IBGE 2006) and geomorphology map (MMA 2006b). In addition, MCT (2016) also exhibited an indirect relationship with the PROBIO map because both used the MCT (2010) vegetation map. The Avitabile et al. (2016) map also had a high SV because it is a fusion of the Saatchi et al. (2011) and Baccini et al. (2012) maps.

The comparison analysis between all AGB map statistics (Fig. 8) reveals that the areas with high standard deviations coincide with the areas of high SV in the three vegetation maps (i.e. SIVAM 2002; IBGE 2004b; MMA 2006a), while no such matches were found in the rest of the environmental factors. This result could mean that there is high uncertainty in the central Amazon (lowland dense humid forests or $\mathrm{Db}$ ) close to the main rivers and in the northeast (submontane dense humid forest or Ds) due to the large size of these vegetation classes; thus, there should be further analysis in these areas (e.g. plot establishment). The same pattern occurs in the forest AGB spatial data gap map.

The forest AGB spatial data gap map (Fig. 9) shows the places with few or no AGB field plots or LiDAR datasets, which are also the places where the AGB maps differ most. In other words, the map of the AGB data gaps represents the priority areas for further AGB assessments. The 5351 AGB field plots that we accessed represent only $0.001 \%$ of the Brazilian Amazon biome area, and the LiDAR data represent $0.197 \%$, meaning that less than $0.2 \%$ of the forest area is sampled (Tejada et al. 2019). Areas with medium weight in the data gap map, where there is a short distance to plots but high standard deviation between AGB maps, could mean that AGB plots and LiDAR transects data were not used for generating AGB maps (perhaps for the limited access to these datasets). The places with the greatest gaps are close to rivers in the States of Amazon, Amapá and northeast and west of Pará, coinciding with the two major vegetation classes (Db and $\mathrm{Ds})$. The vegetation map was used by the Nogueira et al. (2015) and MCT (2016) AGB maps. Considering the large extent, accessibility difficulties and costs to establish field and airborne LiDAR AGB assessments in the Brazilian Amazon, this information is of high relevance for designing further studies.

\section{Conclusions}

The map of the forest AGB spatial data gaps represents the zones with limited information and where the AGB map estimates differ the most. Only $0.2 \%$ of the Amazon biome forest is sampled, and extensive effort is necessary to improve what we know about the tropical forest.

The variance analysis between the environmental factors and AGB data showed that it is important to correctly find an environmental class (or a combination of classes) that represents the AGB as a guideline (IPCC 2006; VCS 2015) to assess the biomass according to the NC and REDD+ recommendations. Our SV analysis should serve as a reference for AGB products and their relationship with environmental factors, not only in Brazil but also in the rest of the countries that will try to obtain AGB maps using IPCC (2006) guidelines recommended under REDD+ projects.

The AGB data gap map could become a useful tool for policy makers and different stakeholders working on $\mathrm{NC}$, REDD+, or carbon emissions modeling to prioritize places to implement further AGB assessments.

\section{Supplementary information}

Supplementary information accompanies this paper at https://doi.org/10. 1186/s40663-020-00228-1.

\section{Additional file 1.}

\section{Abbreviations}

AGB: Aboveground biomass; ALS: Airborne laser scanning; CCST: Earth

System Science Center; EBA: Estimativa de Biomassa na Amazônia, subproject 7 of Remote Sensing Environmental Monitoring of the Amazon Project;

Embrapa: Brazilian Agricultural Research Corporation; ILWIS: Integrated land and watershed management information system; INPA: National Institute of Amazon Research; INPE: National Institute for Space Research of Brazil; LBA: Large Scale Biosphere-Atmosphere Experiment in Amazonia; LiDAR: Light detection and ranging; MRV: Monitoring and measurement, reporting and verification; NFI: National forest inventory; PPBio: The Research Program for Biodiversity; PRODES: Deforestation Monitoring Program; RAINFOR: Amazon Forest Inventory Network; REDD+: Reducing emissions from deforestation and forest degradation, and the role of conservation of forest carbon stocks, sustainable management of forests and enhancement of carbon stocks; TEAM: Tropical Ecology, Assessment, and Monitoring Network; TREES: Tropical Ecosystems and Environmental Sciences Laboratory; TRMM: Tropical Rainfall Measuring Mission; UNFCCC: United Nations

Framework Convention on Climate Change 


\section{Acknowledgments}

We are grateful to Luiz Aragão, Marcos Longo, Luiz Carlos Estraviz, Thelma Krug and Celso von Randow for their valuable contributions to improve this study. We want to thank Michael Keller, Marcos Longo and Maiza Nara dosSantos from the Sustainable Landscapes Project for the field and LiDAR data. For the locations of AGB data, we want to thank Niro Higuchi, Carlos Celes, Moacir Campos and Adriano Lima from INPA, Luiz Aragão from TREES, Marcus Vinicio Oliveira from Embrapa Acre and Joberto Freitas from the National Forest Service. For the AGB maps, we thank Sassan Saatchi, Alessandro Baccini, Euler Nogueira, Valerio Avitabile, and Pedro Valle. We also want to thank American Journal Experts for the English revision.

\section{Authors' contributions}

GT designed the study, undertook the gathering, analysis, and review of the data, and wrote the paper. EBG participated in the study design and conceptualization and study refinement and provided a thorough review of the paper. AOL participated in the spatial and multicriteria analyses and editing of the paper. JPO provided a thorough review and edit of the paper. All the authors read and approved the final manuscript.

\section{Funding}

This study is part of the São Paulo Research Foundation (FAPESP) Grant No. 2013/20616-6 and 2018/18493-7. We acknowledge the contribution of the project LiDAR Remote Sensing of Brazilian Amazon Forests: Analysis of Forest Biomass, Forest Degradation, and Secondary Regrowth funded by the USAID Prime Award Number AID-OAA-A-11-00012. Any opinions, findings, conclusions, or recommendations expressed in this article are those of the authors alone and do not necessarily reflect the views of USAID.

\section{Availability of data and materials}

The datasets used and/or analyzed during the current study are available from the corresponding author on reasonable request.

The datasets supporting the conclusions of this article are included within the article and its additional file.

\section{Ethics approval and consent to participate}

Not applicable.

\section{Consent for publication}

Not applicable.

\section{Competing interests}

The authors declare that they have no competing interests.

\section{Author details \\ ${ }^{1}$ Earth System Science Center (CCST), National Institute for Space Research (INPE), Av dos Astronautas 1758, São José dos Campos, SP 12227-010, Brazil. ${ }^{2}$ Department of Forestry Engineering, Universidade Federal dos Vales do Jequitinhonha e Mucuri, Campus JK, Rod. MGT 367, km 583, 5000, Alto do Jacuba, Diamantina, MG 39100-000, Brazil. ${ }^{3}$ National Center for Monitoring and Early Warning of Natural Disasters (CEMADEN), Estrada Doutor Alino Bondesani 500, São José dos Campos, SP 12247-016, Brazil.}

\section{Received: 20 August 2019 Accepted: 10 March 2020}

\section{Published online: 22 April 2020}

\section{References}

Angelsen A, Brockhaus M, Sunderlin WD, Verchot LV (2012) Analysing REDD+: challenges and choices. Center for International Forestry Research (CIFOR), Bogor. https://doi.org/10.17528/cifor/003805

Avitabile V, Herold M, Heuvelink GBM, Lewis SL, Phillips OL, Asner GP, Armston J, Ashton PS, Banin L, Bayol N, Berry NJ, Boeckx P, de Jong BHJ, DeVries B, Girardin CAJ, Kearsley E, Lindsell JA, Lopez-Gonzalez G, Lucas R, Malhi Y, Morel A, Mitchard ETA, Nagy L, Qie L, Quinones MJ, Ryan CM, Ferry SJW, Sunderland T, Laurin GV, Gatti RC, Valentini R, Verbeeck H, Wijaya A, Willcock $S$ (2016) An integrated pan-tropical biomass map using multiple reference datasets. Glob Chang Biol 22:1406-1420. https://doi.org/10.1111/gcb.13139

Baccini A, Goetz SJ, Walker WS, Laporte NT, Sun M, Sulla-Menashe D, Hackler J, Beck PSA, Dubayah R, Friedl MA, Samanta S, Houghton RA (2012) Estimated carbon dioxide emissions from tropical deforestation improved by carbon-density maps. Nat Clim Chang 2:182-185. https://doi.org/10.1038/nclimate1354
Bernoux M, da Conceição Santana Carvalho M, Volkoff B, Cerri CC (2002) Brazil's soil carbon stocks. Soil Sci Soc Am J 66:888-896. https://doi.org/10.2136/ sssaj2002.8880

Dos-Santos MN, Keller MM (2016a) CMS: LiDAR Data for Forested Areas in Paragominas, Para, Brazil, 2012-2014.

Dos-Santos MN, Keller MM (2016b) CMS: Forest Inventory and Biophysical Measurements, Para, Brazil, 2012-2014.

EBA (2016) EBA - Estimativa de biomassa na Amazônia. In: Melhor. dos métodos Estim. biomassa e Model. Estim. Emiss. por mudança uso da terra. http:// www.ccst.inpe.br/projetos/eba-estimativa-de-biomassa-na-amazonia/. Accessed 6 Jun 2016

Fearnside PM (2018) Brazil's Amazonian forest carbon: the key to southern Amazonia's significance for global climate. Reg Environ Chang 18:47-61. https://doi.org/10.1007/s10113-016-1007-2

Fonseca MG, Aragão LEOC, Lima A, Shimabukuro YE, Arai E, Anderson LO (2016) Modelling fire probability in the Brazilian Amazon using the maximum entropy method. Int J Wildland Fire 25:955-969. https://doi.org/10.1071/WF15216

Goetz SJ, Baccini A, Laporte NT, Johns T, Walker W, Kellndorfer J, Houghton RA, Sun M (2009) Mapping and monitoring carbon stocks with satellite observations: a comparison of methods. Carbon Bal Manage 4:2. https://doi. org/10.1186/1750-0680-4-2

IBGE (2001) Mapa de Solos do Brasil. Brasilia, Rio de Janeiro

IBGE (2002a) Mapa de Clima do Brasil. Brasilia, Rio de Janeiro

IBGE (2002b) Compartimentos do relevo do Brasil. Brasilia, Rio de Janeiro

IBGE (2004a) Mapa de Biomas do Brasil: primeira aproximação. Escala 1:5.000.000 http://ibge.gov.br. Accessed 11 Apr 2016

IBGE (2004b) Mapa de vegetacao do Brasil. Brasilia, Rio de Janeiro

IBGE (2006) Mapa de Unidades de Relevo do Brasil. Brasilia, Rio de Janeiro IBGE, USGS (1992) Mapa de Vegetação do Brasil. Brasilia, Rio de Janeiro

INPE (2015) Amazon deforestation monitoring project (PRODES). http://www.obt. inpe.br/prodes/metodologia.pdf. Accessed 11 Apr 2016

IPCC (2006) IPCC guidelines for national greenhouse gas inventories, vol 4: agriculture, forestry and other land use. In: Eggleston $\mathrm{HS}$, Buendia $\mathrm{L}$ (eds) 2006 IPCC guidelines for national greenhouse gas inventories. Institute for Global Environmental Strategies (IGES), Hayama, pp 1-83

Malkomes M, Fukuda F, Rocheleau F, Werner J (2002) The Sivam project: weather radar network for the Amazon region, Proceedings of the second European conference on radar meteorology (ERAD) in conjunction with COST 717 midterm seminar. Delft, Netherlands, 18-22 November 2002, pp 331-334

MCT (2010) Second national communication of Brazil to the United Nations framework convention on climate change. Brasília

MCT (2016) Third national communication of Brazil to the United Nations framework convention on climate change, vol 3 Brasilia

Meijerink AMJ, Valenzuela CR, Stewart A (1988) ILWIS: the integrated land and watershed management information system: scientific status report on the project GEO information system for land use zoning and watershed management. ITC publication (nr. 7), Enschede, p 115

Mitchard ETA, Feldpausch TR, Brienen RJW, Lopez-Gonzalez G, Monteagudo A, Baker TR, Lewis SL, Lloyd J, Quesada CA, Gloor M, ter Steege H, Meir P, Alvarez E, Araujo-Murakami A, Aragão LEOC, Arroyo L, Aymard G, Banki O, Bonal D, Brown S, Brown Fl, Cerón CE, Moscoso VC, Chave J, Comiskey JA, Cornejo F, Medina MC, Costa LD, Costa FRC, Fiore AD, Domingues TF, Erwin TL, Frederickson T, Higuchi N, Coronado ENH, Killeen TJ, Laurance WF, Levis C, Magnusson WE, Marimon BS, Junior BHM, Polo IM, Mishra P, Nascimento MT, Neill D, Vargas MPN, Palacios WA, Parada A, Molina GP, Peña-Claros M, Pitman N, Peres CA, Poorter L, Prieto A, Ramirez-Angulo H, Correa ZR, Roopsind A, Roucoux KH, Rudas A, Salomão RP, Schietti J, Silveira M, de Souza PF, Steininger MK, Stropp J, Terborgh J, Thomas R, Toledo M, TorresLezama A, van Andel TR, van der Heijden GMF, Vieira ICG, Vieira S, VilanovaTorre E, Vos VA, Wang O, Zartman CE, Malhi Y, Phillips OL (2014) Markedly divergent estimates of Amazon forest carbon density from ground plots and satellites. Glob Ecol Biogeogr 23:935-946. https://doi.org/10.1111/geb.12168

MMA (2006a) Uso e Cobertura da Terra na Floresta Amazônica. PROBIO AMAZÔNIA. São José dos Campos - SP, Brazil

MMA (2006b) PROGRAMA ZONEAMENTO ECOLÓGICO-ECONÔMICO. http://www.mma. gov.br/estruturas/PZEE/_arquivos/diretrizes_2006_parte1.pdf. Accessed 11 Apr 2016

MMA (2015) The implentation of the Warsaw framework for REDD+ by Brazil. http://redd.mma.gov.br/images/publicacoes/wfr-brazil-2015.pdf. Accessed 11 Apr 2016

NFI (2016) Inventário Florestal Nacional - IFN. Inven Florest Nac - IFN, Serviço Florest Bras http://ifn.florestal.gov.br/. Accessed 11 Apr 2016 
Nimer E (1979) Um modelo metodológico da classificação de climas. Rev Bras Geogr - IBGE 41:59-89

Nogueira EM, Fearnside PM, Nelson BW, et al. (2008) Estimates of forest biomass in the Brazilian Amazon: New allometric equations and adjustments to biomass from wood-volume inventories. For Ecol Manage 256:1853-1867. https://doi.org/10.1016/j.foreco.2008.07.022.

Nogueira EM, Yanai AM, Fonseca FOR, Fearnside PM (2015) Carbon stock loss from deforestation through 2013 in Brazilian Amazonia. Glob Chang Biol 21: 1271-1292. https://doi.org/10.1111/gcb.12798

Ometto JP, Aguiar AP, Assis T, Soler L, Valle P, Tejada G, Lapola DM, Meir P (2014) Amazon forest biomass density maps: tackling the uncertainty in carbon emission estimates. Climate Change 124:545-560. https://doi.org/10.1007/ s10584-014-1058-7

Pan Y, Birdsey RA, Fang J, Houghton R, Kauppi PE, Kurz WA, Phillips OL, Shvidenko A, Lewis SL, Canadell JG, Ciais P, Jackson RB, Pacala SW, McGuire AD, Piao S, Rautiainen A, Sitch S, Hayes D (2011) A large and persistent carbon sink in the world's forests. Science 333:988-993. https:/doi.org/10.1126/science.1201609

Pearson T, Walker S, Brown S (2005) Sourcebook for land use, land-use change and forestry projects. Winrock Int BioCarbon Fund World Bank 57 21:64 https://pdfs.semanticscholar.org/4a2f/5bc38244902d0a93cc6d76d1e273e6 d235cf.pdf. Accessed 11 Apr 2016

PPBio (2012) Repositório de dados do PPBio. http://ppbio.inpa.gov.br/repositorio/ dados. Accessed 11 Apr 2016

Quesada CA, Lloyd J, Anderson LO, Fyllas NM, Schwarz M, Czimczik CI (2011) Soils of Amazonia with particular reference to the RAINFOR sites. Biogeosciences 8:1415-1440. https://doi.org/10.5194/bg-8-1415-2011

RadamBrasil (1983) Projeto RadamBrasil. Levantamento de Recursos Naturais. Rio de Janeiro, Brazil

RAINFOR (2015) The Amazon Forest Inventory Network (RAINFOR). http://www. rainfor.org/. Accessed 3 Mar 2015

Saatchi S, Mascaro J, Xu L, Keller M, Yang Y, Duffy P, Espírito-Santo F, Baccini A, Chambers J, Schimel D (2015) Seeing the forest beyond the trees. Glob Ecol Biogeogr 24:606-610. https://doi.org/10.1111/geb.12256

Saatchi SS, Harris NL, Brown S, Lefsky M, Mitchard ETA, Salas W, Zutta BR, Buermann W, Lewis SL, Hagen S, Petrova S, White L, Silman M, Morel A (2011) Benchmark map of forest carbon stocks in tropical regions across three continents. PNAS 108:9899-9904. https:/doi.org/10.1073/pnas.1019576108

SIVAM (2002) Projeto SIVAM. Relatório metodológico de trabalho. Revisão 3. Rio de Janeiro

Sustainable-Landscapes (2016) Sustainable landscapes. https://www. paisagenslidar.cnptia.embrapa.br/webgis/. Accessed 18 Apr 2016

TEAM Network (2016) The Tropical Ecology, Assessment and Monitoring (TEAM) Network. http://www.teamnetwork.org/. Accessed 18 Apr 2016

Tejada G (2014) XI Seminário de Atualização em Sensoriamento Remoto e Sistemas de Informações Geográficas Aplicados à Engenharia Florestal. In: Amazon forest carbon maps, from global IPCC tier 1 to a regional National Communication of Brazil to the UNFCCC tier 2 approach. IEP, Curitiba, pp 519-525

Tejada G, Görgens EB, Espírito-Santo FDB, Cantinho RZ, Ometto JP (2019) Evaluating spatial coverage of data on the aboveground biomass in undisturbed forests in the Brazilian Amazon. Carbon Bal Manage 14:11. https://doi.org/10.1186/s13021-019-0126-8

TREES (2016) Tropical ecosytems and environmental sciences laboratory (TREES). http://trees-research.weebly.com/team.html. Accessed 2 Feb 2015

VCS (2015) Guidance on Use of VCS Tool VT0005. https://verra.org/wp-content/ uploads/2018/03/NCS-Guidance-Use-of-VT0005-16-March-2015.pdf. Accessed 18 Apr 2016

\section{Submit your manuscript to a SpringerOpen ${ }^{\circ}$ journal and benefit from:}

- Convenient online submission

- Rigorous peer review

- Open access: articles freely available online

- High visibility within the field

- Retaining the copyright to your article

Submit your next manuscript at $\boldsymbol{\nabla}$ springeropen.com 